\title{
Turkey Experience in Urban Transformation
}

\author{
Aslı Bozdağำ ${ }^{1}$, Şaban İnam² ${ }^{2}$ \\ ${ }^{1}$ Asst. Prof. Dr., Niğde Ömer Halisdemir University, Engineering Faculty, Geomatic Engineering Niğde, Turkey. Email: \\ aslibozdag@ohu.edu.tr \\ ${ }^{2}$ Asst. Prof. Dr., Konya Technical University, Engineering Faculty, Geomatic Enginerring, Konya, Turkey. Email: \\ sinam@ktun.edu.tr
}

\begin{abstract}
Purpose

This study focuses on the current situation and problems of urban transformation practices in Turkey, with respect to space, society, and policy. A number of field studies and surveys were conducted in the study area in Konya city in Turkey, with regards to the unity of space, society, and politics and were developed spatial strategies that ensure such unity.

Design/Methodology/Approach

The study consisted of two stages. In the first stage, the literature on the need for urban transformation in Turkey was reviewed based on experiences relating to space (land fragmentation, property rights, informalities housing), society (the coordination and participation processes), and politics (current legislation, actors and their roles, horizontal and vertical coordination, public interest, planning strategy, policy learning). In the second stage, a number of field studies (the status of the buildings, the building types, the land use status, the status of historical and cultural structures, the land to building ratio, the land fragmentation and cadastral status and surveys) were utilized within the scope of our analysis. The survey questions consisted of the problems and expectations of inhabitants and NGOs with respect to spatial, political and social aspects of the study area.

\section{Findings}

Based on the results of the current situation analysis and field survey, spatial strategies that provide the unity of space, society, and politics were developed for the study area.

\section{Research Limitations/Implications}

With respect to actors and their roles, this study focuses on two groups as representatives of the social structure. The other groups also should be involved directly or indirectly because of the multifactor structure of the urban transformation processes.

\section{Social/Practical Implications}

Identifying the need, processes and problems related to urban transformation, based on the unity of space, society, and politics could have positive effects on sustainable projects.

Originality/Value

This study is important with the development of spatial strategies with the participation and cooperation activities of the residents and non-governmental organizations (NGOs) on the basis of neighbourhoods in urban transformation.
\end{abstract}

Keywords: Sustainability, urban governance, urban negotiation, urban policy, urban transformation. 


\section{INTRODUCTION}

Urban transformation is an urban regeneration program that involves the rehabilitation of existing parts of a city, the reuse of previously built-up areas and abandoned buildings, and the redevelopment of blighted urban spaces to increase urban sustainability (Rosa et al., 2017). From past to present, urban transformation practices are developing in the context of creating comparative forms of policy and practice, putting more emphasis on integrated treatments in urban areas, having partnership as a dominant approach, creating a good balance between public, private, and voluntary funding, building older areas preserving heritage, and introducing the broader idea of environmental sustainability (Stöhr, 1989; Lichfield, 1992; Roberts, 2004). In the literature, urban transformation has been examined under major themes and topics, such as evolution, definition, and purpose (economic, physical, social, employment, education, and housing) (Roberts \& Skyes, 2000; Noon et al., 2000; Jeffrey \& Pounder, 2002; Jacobs \& Dutton, 2004; Hart \& Johnston, 2006; Edgar \& Taylor, 2008). Furthermore, urban transformation practices have had repercussions in the literature in different urban areas such as architectural studies (Sklair, 2017), the evolution of historical port cities and the process of reconnecting them with the urban structure (Öztürk, 2006; Topçu, 2017), gentrification studies that dominate urban transformation practices (Levy et al., 2006; Lees, 2018), gentrification studies in which real estate came to rule of the city (Stein, 2019), neighborhood transformations led by the cultural structure (Gainza, 2017), culture- and tourism led peri-urban transformation (Li, 2020), and planning of cities as safer and healthier places against global health problems and the threat of a pandemic (Fabris et al., 2020).

In Turkey, the beginning of the EU harmonization process in 1999 and the economic and political crisis experienced in 2001 necessitated significant reforms. This process encouraged political modernization, and significant reforms were made regarding the supply of housing. Since 2002, urban transformation practices in Turkey have attracted significant interest from the construction sector with political support (Afacan, 2015). Urban transformation practices have become an important urban planning interest to create a driving force for the construction sector in physical and economical terms, enable social and cultural investments in space, and ensure justice in the distribution of such investments. Such interest has resulted in conflicts and competition among the actors in the process of sharing and distribution of lands which is a scarce resource, - and securing public interest. This has altered the purpose and meaning of urban transformation practices. To ensure sustainable practices, it is very important to analyse changing definitions, to address the political and social aspects, and to identify associated problems.

In spatial terms, current practices lead to problems such as the creation of spaces that do not reflect the identity of the location where people live 
(Öngel, 2013); investments that are far from having a balanced sector distribution, which is the opposite of what is necessary for a holistic urban planning perspective (Özdemir, 2010); the fragmentation of the space, with social, economic, cultural, environmental, etc. aspects being treated individually and separately (Oatley, 2000); and - from the perspective of the mapping sector - the problem during the projects is that property rights (formal or informal) are sometimes not secured and documented well enough and there is no mixed pattern of rights. Furthermore, there is need for a more sustainable inner-city transformation to address physical and social problems (Zhu \& Huang 2015).

In political terms, these practices bring about problems such as the dilemma of 'satisfying the expectations of actors versus serving the public interest' faced by local administrations (Kreukels \& Spit 1990; Göksu \& Bal 2010; Muñoz-gielen, 2012) the hierarchical structure of local administration coordination that is far from having a reconciliatory character (Bozdağ, 2015) and the development of pseudo-projects based on the ideological choices of local administrators (Tekeli, 2009).

In social terms, the practices bring about problems such as failure to build capacity and cooperation with respect to participatory practices.

In the literature, there are some studies that are examined the urban transformation process from the social, spatial and policy aspects. Güzey, (2009) analysed the legal aspect of the urban transformation processes and, based on the case of Ankara, demonstrated the details of squatter transformation projects and other current projects of the time. Uysal (2012) studied the social aspect of urban transformation based on the case of Istanbul-Sulukule. Özgür (2013) examined the role of urban design projects in urban planning processes, based on two implementation areas in Istanbul. Güzey (2016) discussed the latest urban regeneration law, namely the Law No. 6306 on Regeneration of Areas Under the Risk of Disaster. Ay (2019) analysed the reactions of local people to urban regeneration projects in three neighbourhoods in three different metropoles (Adana, Bursa and Izmir). Turk et al. (2020) analysed the social and spatial aspect of the Fikirtepe Urban transformation Project (Istanbul, Turkey) and focused on the issues of holistic urban transformation project that includes using plan notes to eliminate a co-existence of the commons and the anticommons.

This study primarily examines the needs, processes, and problems of urban transformation in Turkey based on the unity of space, society, and politics to achieve sustainable and successful urban transformation practices defined in the literature. Subsequently, it analyses based on field studies and surveys on space, society, and politics the study area in Meram Municipality, Konya, Turkey, and develops spatial strategies to ensure the unity between the aforesaid three concepts. Finally, with this study, spatial strategies were developed with the participation and cooperation activities of neighbourhood residents and NGOs. 


\section{MATERIAL AND METHODS}

Urban transformation practices lead to the development of significant spatial-functional strategies for the resolution of problems relating to the property structure in urban areas, the transformation of the property structure, and the development of land use policies.

While urban transformation practices in Turkey are gradually pervading, there are still certain issues and shortcomings. To avoid such issues, this study proposes recommendations based on the unity of space, society, and politics regarding spatial strategies developed within the framework of a case study.

The study area is in the city centre of Konya (Figure 1). Konya is the largest province in Turkey in terms of surface area, and has a population of 2,108,806 according to 2015 data. Konya is a developed city with its considerable historical, cultural, economic and agricultural wealth. Konya was the capital city of the Anatolian Seljuk Sultanate, and has many significant sites within its border. Çatalhöyük, which is included in UNESCO's World Heritage List, is one of the most ancient settlements in history. The Tomb of Mevlana is another important site, particularly in terms of religious tourism.

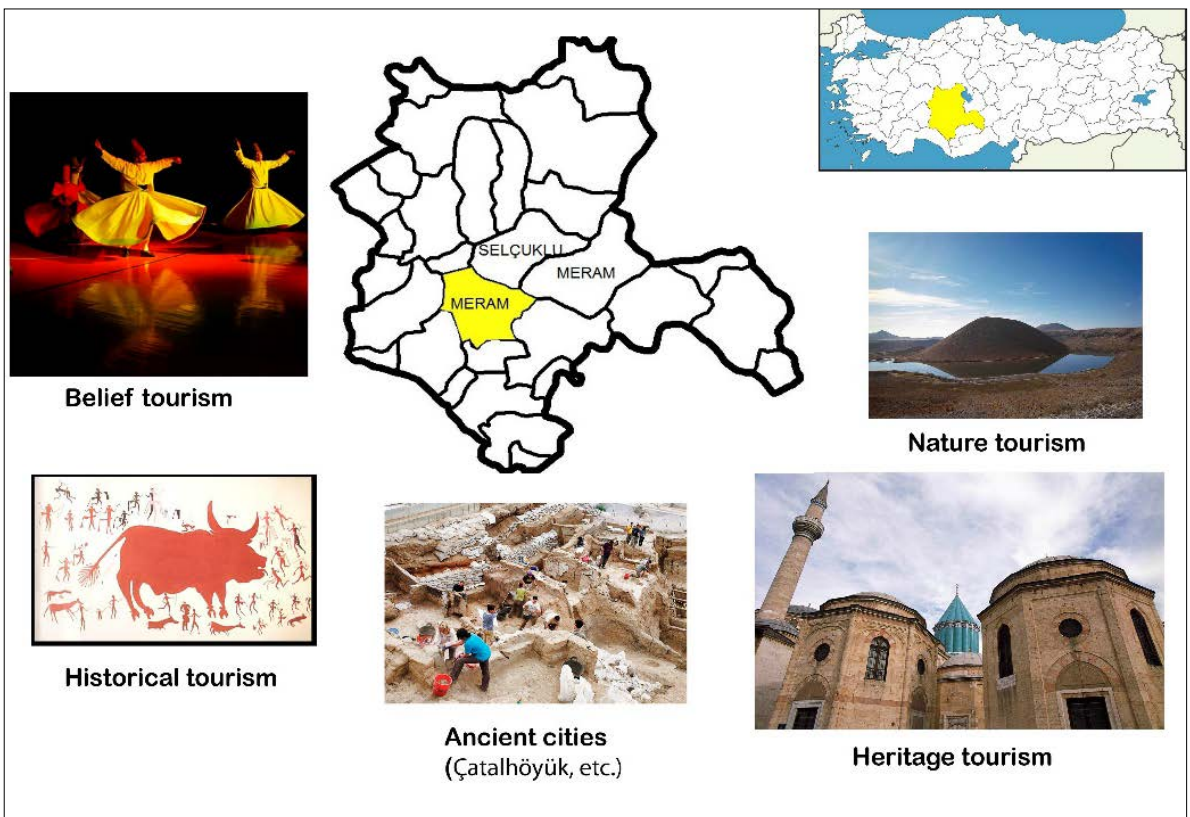

The study area, which has a surface area of 55 hectares, was designated by the Council of Ministers as a risky area in accordance with the Law Number 6306 on Urban Regeneration in Areas under the Risk of Disaster. Due to property problems and the presence of historical and cultural structures that require preservation, the project will be carried out in several stages. The Şükran Neighbourhood was selected for the first stage (painted in red in Figure 2).

Şükran neighborhood transformation application is orchestrated by the Ministry of Environment and Urbanization and Meram Municipality. The executive firm was determined by the Ministry of Environment and
Figure 1. General view of Konya (source: Konya general overview) 
Urbanisation, TOKI presidency through a tender. While a ground survey, excavation, and application project is carried out by the executive firm, archeological studies are carried out for the purpose of finding historical remains by the Monuments Board.

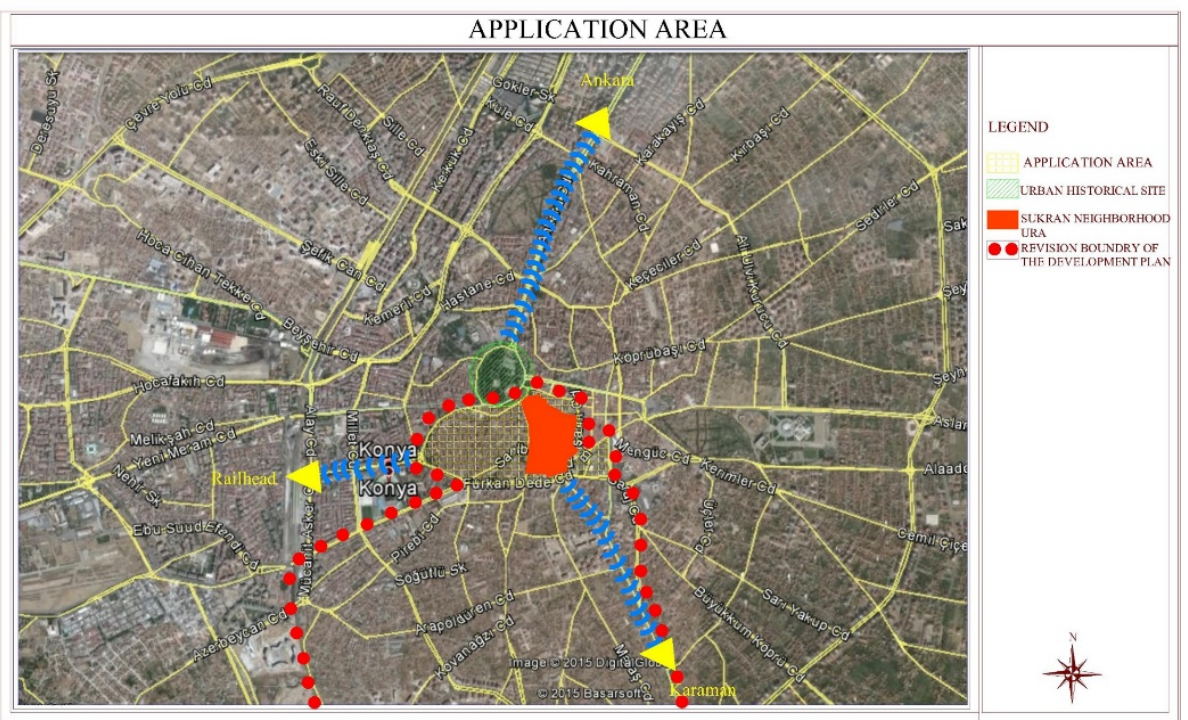

Figure 2. The urban transformation study area in Meram Municipality

The Şükran Neighborhood was selected for this study because:

- It encompasses the old city of Konya.

- It is important to renew in terms of touristic areas and the image of the city.

- There are lots of informalities housing resulting from increased population.

- There are fragmented ownership and inheritance problems due to its location in the old city center.

- The historical identity and urban fabric were deteriorated in the area.

The purpose of this study is to develop spatial strategies that are based on the unity of space, society, and politics for urban transformation in the Şükran Neighborhood.

The study consisted of two stages because of the study propose. In the first stage, the literature on the need for urban transformation in Turkey was reviewed based on experiences relating to space, society, and politics, and current problems were identified.

- The spatial aspect of urban transformation practices in Turkey was analyzed by considering the primary issues (land fragmentation, property rights, informalities housing)

- The political aspect of urban transformation practices in Turkey was analyzed by considering current legislation, actors and their roles, horizontal and vertical coordination, public interest, planning strategy, policy learning, and methods of transformation. 
- The social aspect of urban transformation practices in Turkey was analyzed by considering the coordination and participation processes.

In the second stage, a number of field studies and surveys were utilized within the scope of our analysis. The aim of the field studies is to examine how the status of the buildings, the building types, the land use status, the status of historical and cultural structures, the land to building ratio, the land fragmentation and cadastral status, and the morphology of land use situation. The field studies helped with the identification of the current physical structure of the study area on maps, and with deriving significant conclusions that would guide spatial strategies. The maps, which were received from the local administration and the cadastre, were updated in the implementation area.

The surveys were conducted together with the inhabitants and NGOs. The reason these two groups were selected is to ensure their active participation in the planning process and develops spatial strategies that ensure the unity between spatial, political and social aspects in the study area. There are 2261 shareholders in the implementation area. The sampling volume for the local inhabitants was determined as 327 persons based on a 95\% confidence level, and for different main mass sizes. Simple random sampling technique was used. The sampling number of NGOs was determined as 30 participants based on a $95 \%$ confidence level according to a standard table on acceptable sample sizes (Altunışı et al. 2010). The number of participants in the sample is sufficient to determine characteristics in Konya urban center as statistical. Professional chambers associated with urban transformation practices were preferred as NGOs' participants. Participants consist of surveyor, city planner, architects, chamber of civil and geological engineers, president, vice president and members. The survey questions consisted in order to determine the problems and expectations of inhabitants and NGOs with respect to spatial, political and social aspects of the study area.

Finally, based on the results of the current situation analysis and field survey, spatial strategies that provide the unity of space, society, and politics were developed for the study area.

\section{THE NEED FOR URBAN TRANSFORMATION IN TURKEY}

Turkey has experienced a rapid urbanization process since the 1950s (Iban, 2020). In 1940-1950, the migration from rural to urban areas gradually began, and the newcomers needed to settle upon public lands to start up their lives in the cities. In 1950-1960, since there was no mass housing, there was no possibility of acquiring houses with long-term credit, and there were no cheap/affordable lands with the existing infrastructure. Therefore, those who migrated from rural areas to cities created their own housing on public lands (Akın \& Özdemir, 2010). Thus, a squatting process started, in which low-income migrants coming from rural areas solved their property and housing problems using informal methods. During the same period, the 'Property Ownership Law,' enacted, 
was the only instrument to produce housing for middle-income citizens (Işık, 1995). The Property Ownership Law led to the demolition of buildings that had completed their lifetime and the construction of apartment blocks in their place. However, this eventually led to issues of infrastructural inadequacy. These methods failed to supply mass housing in urban spaces or areas.

In the period from 1980, the government enacted mass housing projects and provided comprehensive formalization. Furthermore, the authorities of the central government were transferred to local governments. Private sector investors, who made significant investments in squatter areas and led to changes in income levels at the periphery of cities, were included in this process. It can be said that this period, in general, witnessed the first appearance and introduction of urban policies and regulations. However, legal regulations - especially those related to amnesties for squatters - have not been able to ensure spatial and functional fairness or social justice. The reason for this is the political interventions in land use and property.

In 2005, Article 73 of Municipality Law No. 5393 provided municipalities with the authority to implement urban regeneration projects. This article did not enable any transformation project since it did not have any implementation regulation. Therefore, the municipalities did not know how to implement projects and solve problems related to property rights. Instead, the municipalities tended to implement projects by the Law on Conservation of Cultural Properties at the beginning of the 2000s.

According to the aforementioned legislation, the entire decision-making authority rests on the local authorities, with no opportunity for participation being offered to the population (Cahantimur et al., 2010). Nevertheless, a number of projects were developed to resolve some of the problems of the time, and to facilitate supply of housing. Projects developed in cooperation with the Mass Housing Administration (TOKI), in particular, have mobilized the construction sector all over the country. Following the 2011 earthquake in Van that led to many deaths, the government took a significant action in 2012 and introduced the Law No. 6306 on Urban Regeneration in Areas under the Risk of Disaster.

Throughout this process, the need for urban transformation in Turkish cities has also been described by various academicians, and the relevant legislation and practices have brought about certain discussions on the triad of space, society and politics. The review of some studies on the issues of urban transformation in Turkish cities with respect to space-, society- and politics-related considerations can be briefly summarised as shown in the following Table 1.

When Table 1 is examined, it can be determined in which direction urban transformation projects are concentrated in Turkey according to their subject in academic studies. In this sense, it can be said that there is a significant trend regarding the restructuring of squatter areas, providing affordable housing, physical and social transformation for different ethnic groups or neighborhood associations, redesigning and 
functionalizing historical places by preserving them. It has been determined that other remarkable issues in urban transformation practices are disaster risk, environmental pollution, and improving the socio-economic structure.

Table 1. A review of some studies on the issues of urban transformation in Turkey

\begin{tabular}{|c|c|c|c|c|c|c|c|c|c|c|c|c|c|c|}
\hline & 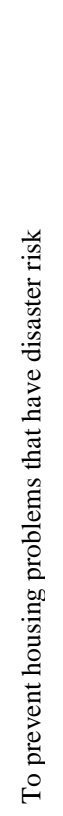 & 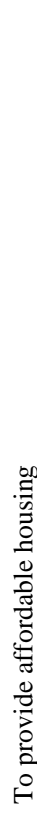 & 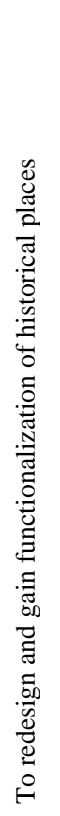 & 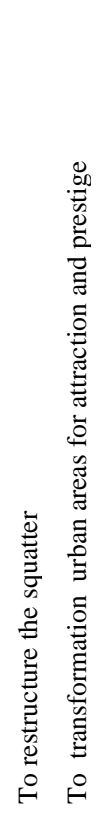 & 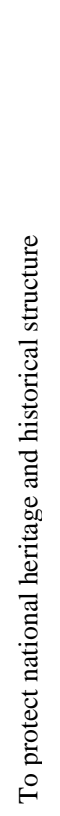 & 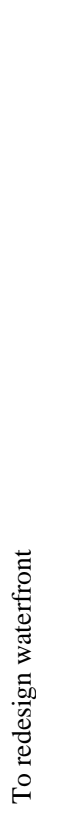 & 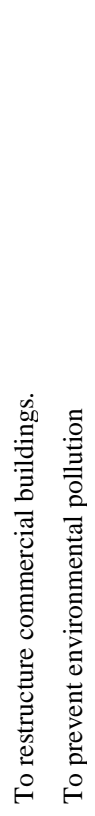 & 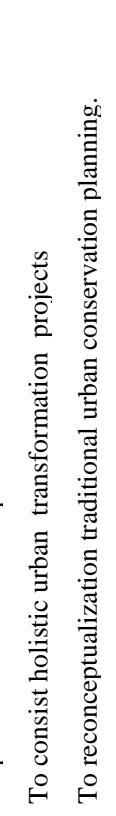 & 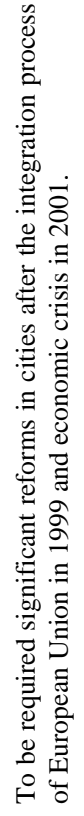 & 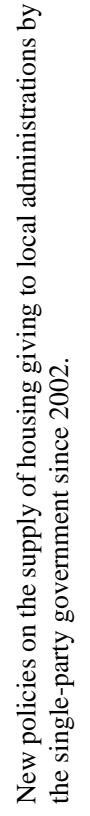 & 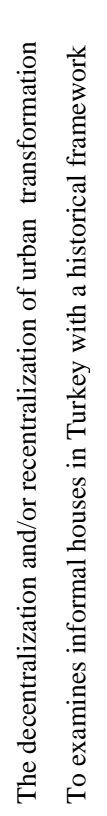 & 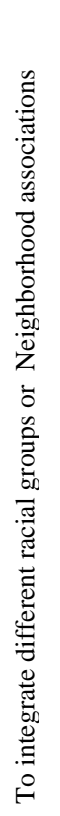 & 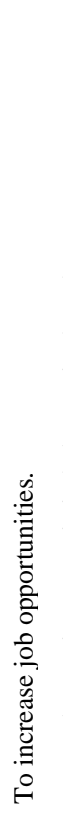 & 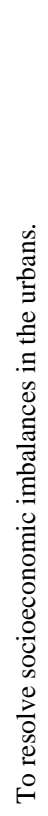 \\
\hline $\begin{array}{l}\text { Dündar, } \\
2001\end{array}$ & & $\mathrm{X}$ & & $\mathrm{X} \quad \mathrm{X}$ & & & & & & & & & & $\bar{X}$ \\
\hline $\begin{array}{l}\text { Kocabaş, } \\
2006\end{array}$ & $\mathrm{X}$ & $\mathrm{X}$ & $\mathrm{X}$ & & $\mathrm{X}$ & & & $\mathrm{X}$ & $\mathrm{X}$ & $\mathrm{X}$ & & & & \\
\hline $\begin{array}{l}\text { Eyüboğlu } \\
\text { et al. } \\
\text { (2007) }\end{array}$ & & & $\mathrm{X}$ & & $\mathrm{X}$ & & & & & & & & & \\
\hline $\begin{array}{l}\text { Güzey } \\
\text { (2009) }\end{array}$ & & $X$ & & $\mathrm{X}$ & & & $\mathrm{X}$ & & & & & & $\mathrm{X}$ & \\
\hline $\begin{array}{l}\text { Bostan et } \\
\text { al. (2010) }\end{array}$ & & & & & & & $\begin{array}{ll}X & X\end{array}$ & & & & & & & \\
\hline $\begin{array}{l}\text { Ercan } \\
\text { (2011) }\end{array}$ & & $X$ & $\mathrm{X}$ & & $\mathrm{X}$ & & & & & & & $\mathrm{X}$ & & $\bar{X}$ \\
\hline $\begin{array}{l}\text { Uysal } \\
\text { (2012) }\end{array}$ & & & $\mathrm{X}$ & & $\mathrm{X}$ & & & & & & & $\mathrm{X}$ & & \\
\hline $\begin{array}{l}\text { Günay \& } \\
\text { Dökmeci } \\
\text { (2012) }\end{array}$ & & & $\mathrm{X}$ & & $X$ & & & & & & & & & \\
\hline $\begin{array}{l}\text { Batuman } \\
\text { (2013) }\end{array}$ & & $X$ & & $\mathrm{X}$ & & & & & & & & & & \\
\hline $\begin{array}{l}\text { Kayasü } \\
\& \\
\text { Yetiskul } \\
\text { (2014) }\end{array}$ & & & & & & & & & $\mathrm{X}$ & & & & & \\
\hline $\begin{array}{l}\text { Uzun \& } \\
\text { Simşek } \\
\text { (2015) }\end{array}$ & & $\mathrm{X}$ & & $\mathrm{X}$ & & & & & & & & & & \\
\hline $\begin{array}{l}\text { Eğercioğl } \\
\text { u, et al. } \\
\text { (2016) }\end{array}$ & & & $\mathrm{X}$ & & $\mathrm{X}$ & & & & & & & & & \\
\hline $\begin{array}{l}\text { Guzey } \\
\text { (2016) }\end{array}$ & $\mathrm{X}$ & & & $\mathrm{X}$ & & & & & & & & & & \\
\hline $\begin{array}{l}\text { Ay, } \\
\text { (2019) }\end{array}$ & & & & & & & & & & & $\mathrm{X}$ & $\mathrm{X}$ & & \\
\hline $\begin{array}{l}\text { Turk, et } \\
\text { al. (2020) }\end{array}$ & & & & $\mathrm{X}$ & & & & $\mathrm{X}$ & & & & $\mathrm{X}$ & & \\
\hline $\begin{array}{l}\text { Iban, } \\
(2020)\end{array}$ & & & & & & & & & & & $\mathrm{X}$ & & & \\
\hline
\end{tabular}




\section{The Spatial Aspect of Urban Transformation Experience in Turkey}

One may say that the purpose of urban transformation practices in Turkey is to ensure the proper planning of land use and to develop property allocation strategies in problematic urban areas. However, in practices performed within squatter areas, urban transformation inadvertently results in gentrification due to the displacement of local communities or the provision of benefits to other (i.e. non-local) groups. Similarly, in examples where socio-economic and socio-cultural uses are not duly considered, the transformation practices become nothing more than restructuring of lands and building areas.

In urban transformation practices, the primary issues that are encountered with respect to the spatial aspect are listed below:

- During the identification of the limits of the implementation area, due attention should be paid to avoid fragmentation of the urban space. For example, proper identification of neighborhood limits, protected area limits, etc. would help maintain the holistic nature of the transformation project.

- In Turkey, property rights and rules on land use are not clearly defined before land use planning is performed.

- No studies are performed on the morphology of the land use. For this reason, there are similarities in the practices and approaches implemented in different regions with different identities. Performing a morphology of land use analysis before transformation activities, and carrying out practices based on such analysis, might ensure that the land use planning reflects the urban identity, thus enabling a holistic planning for the city.

- There is no framework for ensuring that the increase in land value before and after transformation are balanced, that the earned income is used for the public benefit, and that the necessary spatial and functional policies and strategies are developed. To balance the changes land value, one possible approach would be to perform balancing development/construction right transfers on the boundaries of these areas (such as the revision of construction plans) that would serve the public interest.

- In implementation areas; there are various problems such as outdated cadastre maps, conflicts between the boundaries shown on maps and the actual ones on the field, incomplete studies on cadastral renovation, and inheritance and shared property problems for deeds in city centers. Since urban transformation is an ex-officio practice, it is a significant tool for regulating property ownership and solving legal and technical problems.

The Political Aspect of Urban Transformation Experience in Turkey In order to demonstrate the political aspects of the Turkish experience, urban transformation practices - which represent an instrument for regulating urban space for local and central administrations - should be analysed in association with political dynamics. The political dynamics of 
practices in Turkey can be evaluated based on the following aspects: current legislation, actors and their roles, horizontal and vertical coordination, public interest, planning strategy, policy learning, and methods of transformation.

Current legislation: Since 2012, urban transformation practices have been conducted in line with Law No. 6306 on Urban Regeneration in Areas under the Risk of Disaster. The practices performed under this legislation were analysed with respect to the aforementioned political dynamics.

Actors and their roles: Under the framework of the legislation mentioned above, almost all authorities have been concentrated in the Ministry of Environment and Urban Planning, which is a central administration. If the Ministry deems appropriate, it may delegate authorities to TOKI (Mass Housing Administration) or local administrations. The authority of local administrations in designating urban transformation areas has been eliminated, with local administrations now having solely the authority to "propose" or "recommend" areas for urban transformation.

For local administrations, urban transformation projects in risky areas are quite significant to promote urban development and to increase their votes in the future. In this context, when such an authority is delegated from the central administration to the local administration; local administrations supply TOKI with the land, and establishes a "coalition" with TOKI to ensure that the cost of the investment is covered by TOKI. Thus, TOKI contributes to urban development based on coalitions with local administrations. Furthermore, thanks to economic coalitions with local administrations, TOKI generates income for social housing production.

Actors and their roles are presented briefly in (Figure 3). (Bozdağ, 2015)

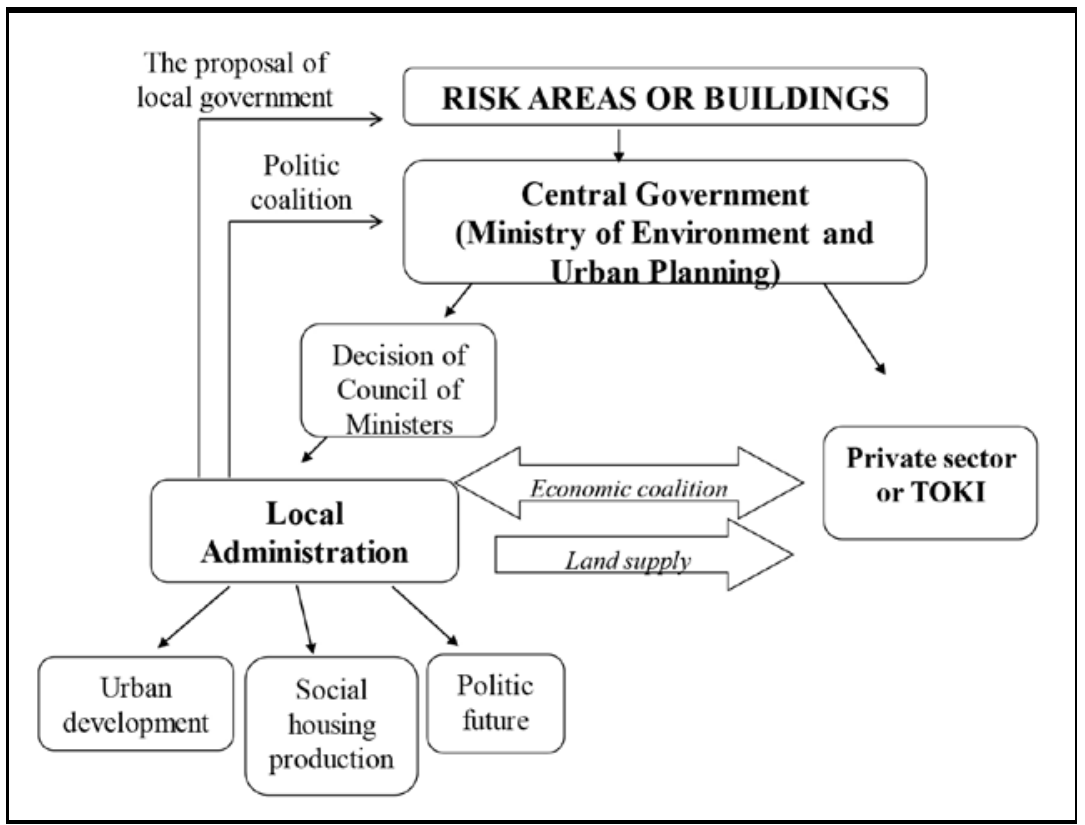

Figure 3. Actors and their roles in urban transformation process (Palancioğlu \& Cete, 2014; Zhang, 2014; Bozdağ, 2015) 
Horizontal and vertical coordination: Under this law, the central administration plays a significant and prominent role. In this case, the scope of the Law implies a hierarchical structure and vertical coordination, based on strong accountability of representative democracy. However, urban transformation practices are multi-actor practices. Sustainable practices require social and spatial coordination at horizontal level and a planning perspective, which is rather based on a supervising function at vertical level.

Public interest: In implementation, the principle is to ensure the consent of the two thirds of proprietors. In case no agreement is reached or the building under risk is demolished, the immovable under the ownership of real or legal entities are urgently expropriated by the Ministry, TOKI or the municipality. During expropriation, both public interest and personal interests should be taken into consideration (Üstün, 2009).

Planning strategy: Within the scope to the law, urban transformation practices can be implemented in three cases, which are risky areas, reserve areas, and buildings under risk. Risky areas can be determined based on the proposal of the Ministry/administrations and the decision of the Council of Ministers. Moreover, property owners can apply to private offices to check the physical safety of their buildings, and they can have some benefits if the building is certified as risky. On the other hand, reserve areas and buildings under risk can be designated by the Ministry (Bektaş, 2014).

Plans prepared under the relevant Law may not be subject to the impeding provisions of the Public Works Law, the Forestry Law, etc., or to provisions from other laws that are contrary to the relevant Law concerning urban transformation (Bektaş, 2014). For instance, the plans may not fully adhere to the social and technical infrastructure standards defined in the Public Works Law. Similarly, the Law on Preservation of Cultural and Natural Properties is quite significant for the preservation and improvement of the existing cultural fabric. The Law stipulates that principles on preservation of the cultural fabric are taken into consideration in the planning of risky areas or buildings. While this approach accelerates the bureaucratic processes related to risky areas, they might also lead to the omission of basic planning principles.

Under the Law, special standards can be developed, planning decisions based on such standard can be performed, and urban design projects can be developed.

Policy learning: The Law aims not only to prevent earthquake hazards, but also to create legal and safe living environments in areas such as unlicensed buildings that are already in use. However, the outcomes are generally unsatisfactory due to the fact that examples from foreign countries are articulated into the projects, similar projects are developed in almost all cases, and the environmental, cultural and social aspects are not reflected in the implementation.

Methods of transformation: Tekeli (2009) described transformation methods in three groups: 
The first group is the projects that involve the transformation of squatterlike areas to urban areas; the second is the gentrification projects that occur in city centres; and the third is the pseudo projects that stem from the ideological preferences of local administrations (Özdemir, 2010).

To these transformation methods, one should also add projects related to areas and under the risk of disaster, and reserve areas, which are within the scope of the Law enacted in 2012.

The aim is thus to develop a rapid and comprehensive transformation process in disaster areas that will not be hindered by bureaucratic barriers. However, it may be said that the practical scope of this method is to facilitate urban transformation required in every sense in urban and rural areas and to create an economic dynamism by mobilizing the immovable property market.

\section{Social Aspect of Urban Transformation Experience in Turkey}

The social aspect of urban transformation practices in Turkey was analysed by considering competitive approaches and the relevant coordination and participation processes.

Competitive approaches: Actors involved in the implementation have many spatial-functional strategies such as satisfying the public interest, generating maximum income, and achieve better life standards. They are in competition and conflict with each other in pursuance of their own strategies to the maximum level. Such competitive approach, in turn, results in disparities with respect to spatial-functional justice, owners' expectations on property, public interest, and spatial-functional quality. Prevention of such conflict requires creation of an urban governance network that ensures horizontal coordination in public administration (Muñoz-gielen, 2012). Since the 20th century, urban governance network has been offering new tools for citizens to make decisions on development of the cities they live in (Roman'czyk, 2015). Urban governance also increases the competitive capacity of cities in attracting and retaining capital and people (Oakley, 2011). However, urban governance should not be depoliticized in order to establish a consensus between public and private stakeholders and attention should be paid to strengthen social structure by making democratic decisions between all stakeholders (Swyngedouw, 2005; Oakley, 2011; Williamson \& Ruming, 2019).

Coordination and participation: In technical sense, the urban transformation process in Turkey comprises the following activities: identification and analysis of the current situation, identification of the parameters of urban transformation, and actions towards the applications (Figure 4). Administration is the main actor in these processes. The first phase of this process is the preparatory process, where the administration ensures coordination with relevant institutions and inhabitants. The participatory technique used for coordination aims to collect information and data before the planning phase. In the second phase of the process, the administration ensures coordination with the 
departments thereunder and the funders that bear the costs of the implementation. The aim is to identify the parameters of the urban transformation. This phase comprises the planning process, which is not based on participatory techniques in Turkey. The last phase of the process involves actions aimed at implementation. In this phase, the administration builds coordination with NGOs (civil society organizations) and stakeholders to ensure post-planning transition to the implementation phase. The participatory techniques used within the context of such coordination are consultation, placation, and negotiation (Eğercioğlu et al., 2016).

Arnstein (1969) analyses the participatory practices and suggests a classification. The classification involves three groups of participatory techniques (non-participation, degrees of tokenism, and degrees of citizen power). We analyzed the ideal participation techniques of orchestrating the urban transformation projects in Figure 4. While the first and third phases involve degrees of tokenism, the second phase is non-participatory. The first and second phases of the participation technique have been implemented in Turkey. Although there are studies on the participation technique in the 3rd phase, the participation success is not at the desired level.

Figure 4. Coordination process and participatory techniques in urban transformation (Uzun \& Şimşek 2015), (Bozdağ 2015).

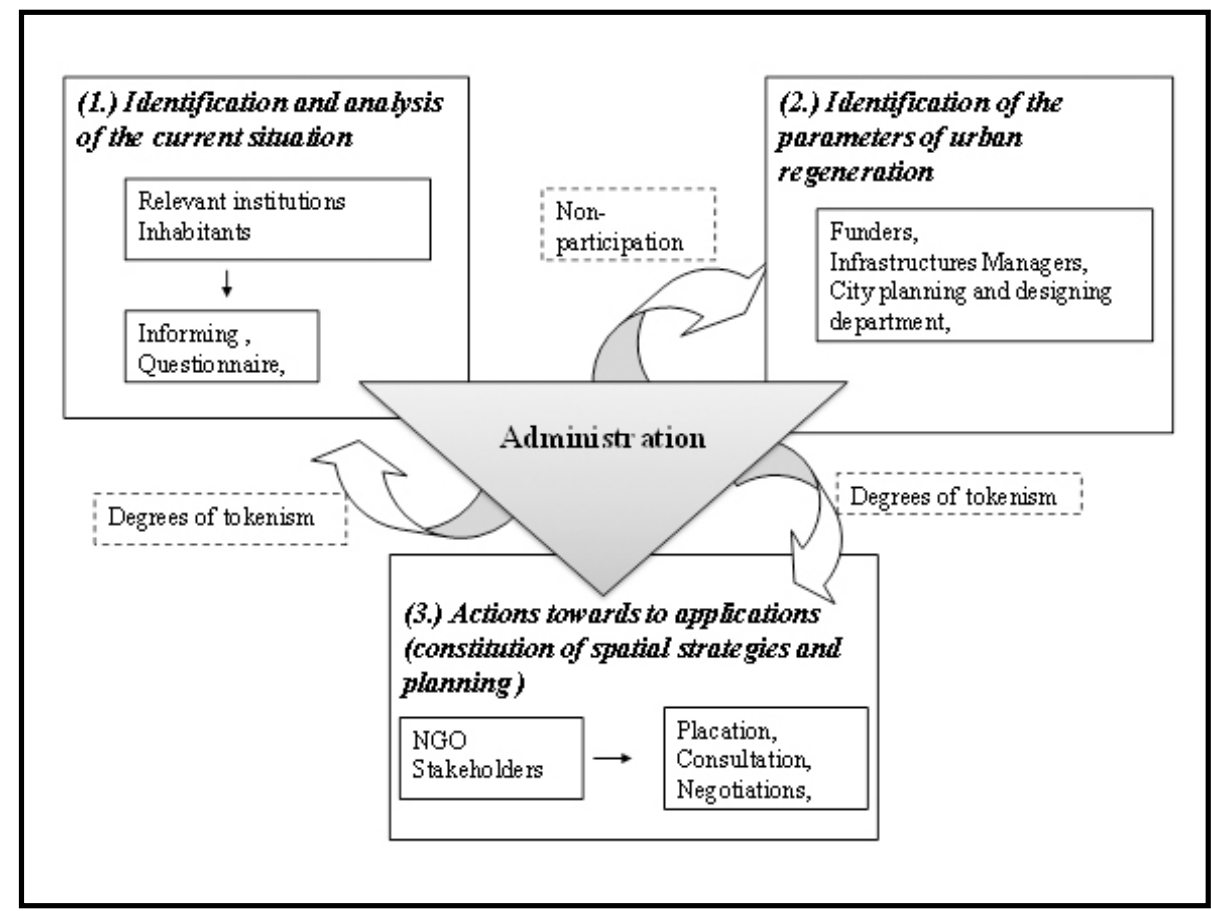

There are approaches and attitudes that make it difficult for actors to build coordination. The following factors particularly complicate the effectiveness and success of coordination efforts:

- Local administrations' rigid attitude towards participation and negotiation processes (Özden, 2010),

- Ideological approaches of professional chambers, 
- The hierarchical structure resulting from strong accountability in representative democracy leads to conflicts of authority in multistakeholder practices, such as urban transformation practices (Bozdă̆, 2015),

- Failure to manage the urban profiles with cultural diversity (Tallon, 2010),

- Erroneous implementation of participatory methods (participatory practices that are not comprehended at local level, that increase confusion among stakeholders who are expected to act together, that raise the expectations of the population, and that decrease satisfaction), and

- Deeming participatory practice as unnecessary or drudgery.

This complicates the governance process established between local administrations and other competent bodies (Tallon, 2010). Yllmaz (2007) described that "due to structural problems such as organizational failures, structural problems, personnel, tools and instruments, methods, and bureaucratic culture; an organizational and functional reform is needed in Turkey in the area of in public administration."

\section{URBAN TRANSFORMATION EXPERIENCE IN TURKEY; THE CASE OF KONYA}

In the study area, a number of field studies and surveys intended for space, society, and politics were conducted.

\section{Field Studies on the Current Structure}

Field studies helped identify the status of the buildings, the building types, the land use status, the status of historical and cultural structures, the land to building ratio, the land fragmentation and cadastral status.

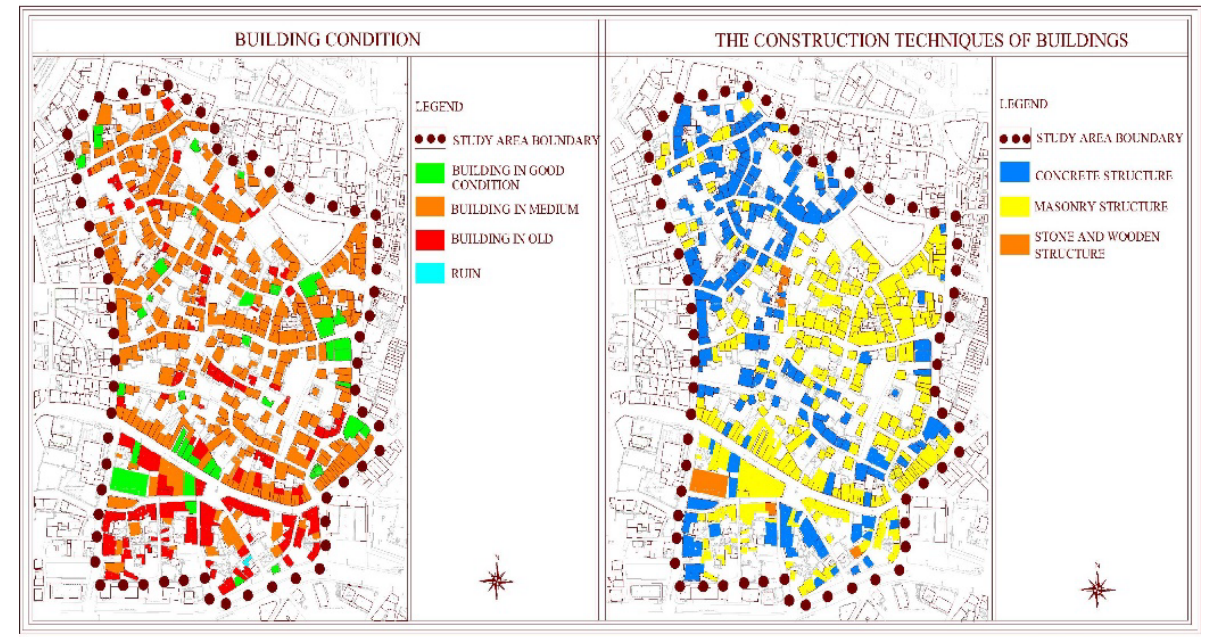

In the implementation area, there are quite a few buildings in good condition. The buildings are at least 30 years old. The building type is generally concrete and masonry structure (Figure 5). The buildings on
Figure 5. Building condition and construction technique of buildings 
the main street, which are in bad condition, were generally built by the stone masonry technique.

Figure 6. Land use and historical and cultural building condition of urban transformation area

Figure 7. The floor area ratio and land fragmentation density on property rights

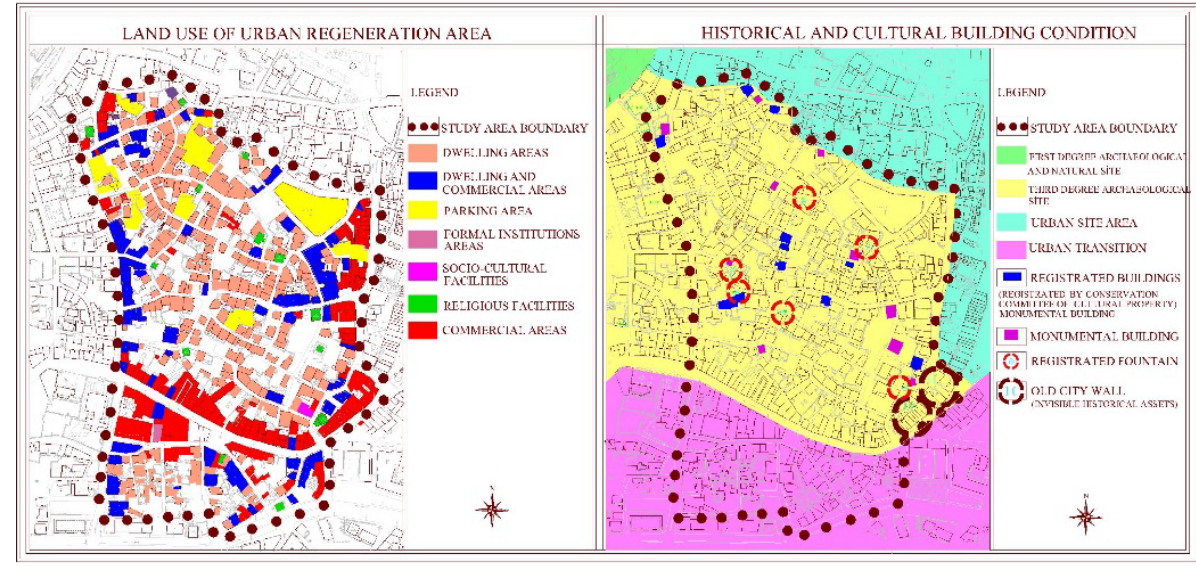

In terms of land use; while dwelling use and dwelling + commercial use was observed at the centre of the area, there is an increased level of wholesale commercial use on the main street axes (Figure 6). Although there are two legal parking areas on the zone, there are other parking areas formed illegally on idle/unused lands. There is only a single sociocultural facility, which is insufficient in terms of quality and capacity.

The implementation area is located at the border of the urban site (protection) area, within a third degree archaeological site area and an urban transition zone (Figure 6). The area includes registered buildings, monumental buildings, and registered fountains. Geo-radar ground inspection was also carried out in the implementation area. Fortification walls belonging to the old city (and which are no longer visible) were identified under the ground.

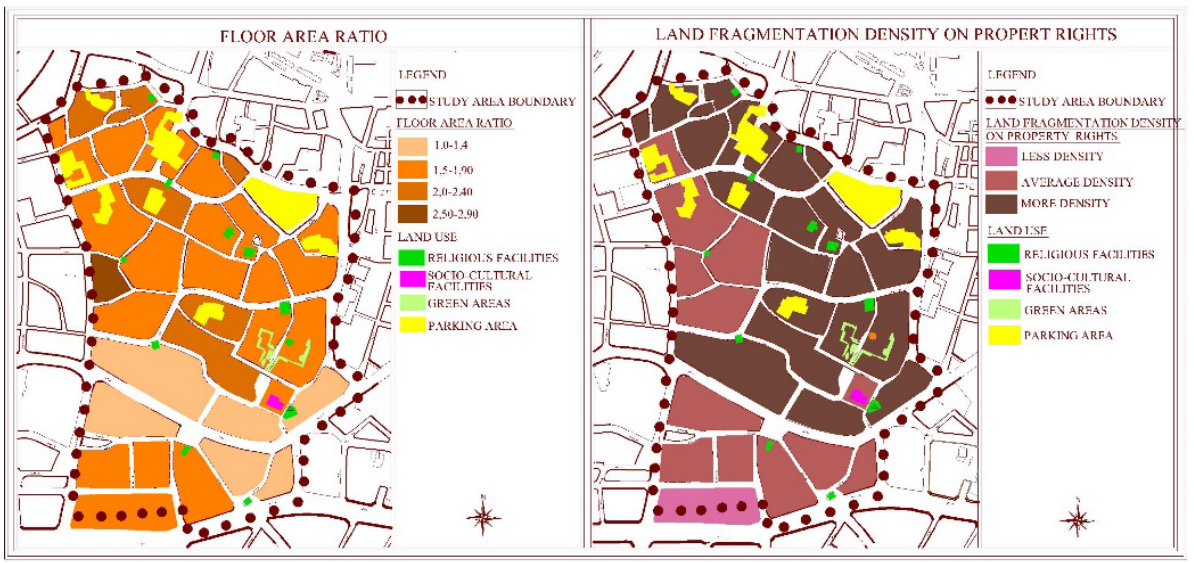

The floor area ratio is generally low in the implementation area (Figure 7). Buildings used for commercial purposes on the main street, in particular, consist mainly of single-floor buildings. This results from the fact that the area is the old city centre. Furthermore, fragmented ownership is also quite frequent in the area. 
Since the implementation area is an old city centre, fragmentation of ownership of the lands is also quite common (Figure 7). It has been described that the main reason for such fragmentation of property rights is the problems relating to inheritance (Meram Municipality). Due to inheritance problems that have yet to be legally resolved, the cadastral situation has not been updated.

\section{Surveys}

Within the frame of the survey, the participants were consulted on the following matters:

- Their opinion on the current situation (problems),

- Their expectations on the spatial strategies to be developed, and

- Their needs in terms of having a say and responsibility in the process.

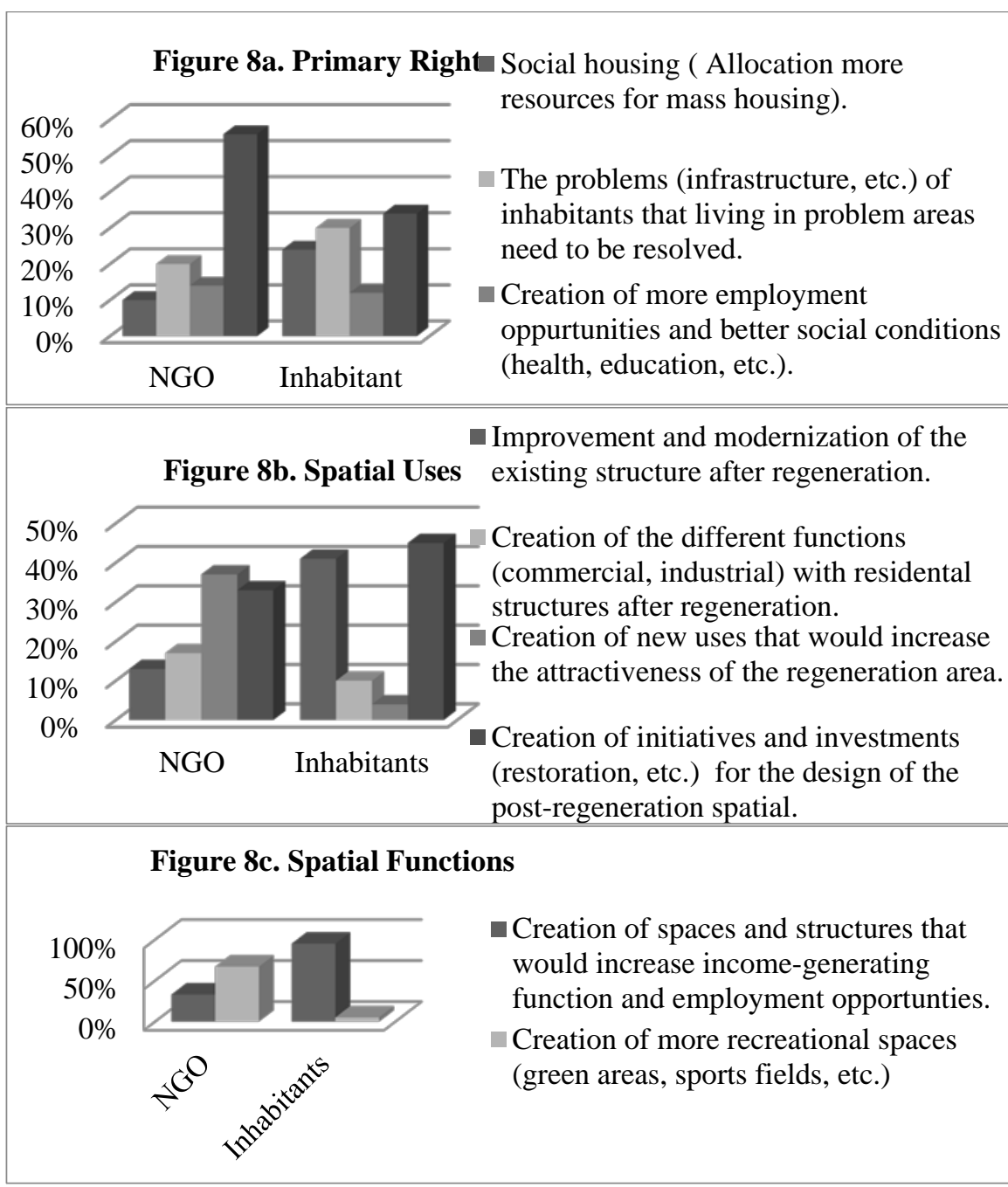

In the implementation area, the participants were consulted on the use of the current structure and current problems concerning its near vicinity. Regarding the use of the current structure, both participant groups considered the advanced age of buildings, and insufficiency of parking areas, gardens, and patios as the main problems. While NGOs consider tall
Figure 8. The expectations from the municipality within the context of the implementation (Figure 8a. Primary Rights, Figure $8 b$. Spatial Uses, Figure 8c. Spatial Functions) 
storey heights as a planning problem, inhabitants considered low number of rooms as a problem with respect to the use of the current structures. Regarding the near vicinity of the current urban structure, both participating groups considered parking areas, roads, and streets insufficient in terms of both physical conditions and safety. Unlike the local inhabitants, NGOs also mentioned problems related to recreational areas and architectural view in the near vicinity.

The participants were consulted on the primary rights, spatial uses, and spatial functions that they are expecting from the local administration following the transformation activities.

Both groups of participants had expected to have a greater say regarding the implementation (Figure 8a). The next most important expectations of the participant groups were resolving the problems of inhabitants living in problematic areas, and allocating more resources for mass housing. Expectations related to spatial use were different for both groups (Figure $8 b)$. What is common for both groups is that there is an expectation for initiatives for the design of the post- transformation space. While inhabitants expected improvement and modernization of the existing structure, NGOs expected the creation of new uses based on its potentials, and efforts that would increase the appealed of this space/area.

Concerning spatial functions, local inhabitants expected the inclusion of income-generating functions, which would also increase employment opportunities, while NGOs expected the creation of more recreational spaces (Figure 8c).

Figure 9. The expectations from the municipality within the processes of participation and cooperation activities (Figure 9a. Participation Activities, Figure 9b. Cooperation Process)

\begin{tabular}{|c|c|}
\hline Figure 9a. Participation Activities & Figure $9 \mathrm{~b}$. Cooperation Process \\
\hline $35 \%$ & $50 \%$ \\
\hline $30 \%$ & $40 \%$ \\
\hline $\begin{array}{l}25 \% \\
20 \%\end{array}$ & $30 \%$ \\
\hline $\begin{array}{l}20 \% \\
15 \%\end{array}$ & $20 \%$ \\
\hline $10 \%$ & $10 \%$ \\
\hline $5 \%$ & \\
\hline Inhabitant & Inhabitant \\
\hline $\begin{array}{l}\text { Participation applications (surveys, symposia, } \\
\text { workshops, seminars, conferences, etc.)shoul d be } \\
\text { done on a sustainable basis for urban regeneration. }\end{array}$ & $\begin{array}{l}=\text { Ideological views of the municipalities are } m \text { ore } \\
\text { important than the cooperation in the } \\
\text { applications. }\end{array}$ \\
\hline $\begin{array}{l}\text { Training programs should be organized in order to } \\
\text { understand the participation applications. }\end{array}$ & $\begin{array}{l}\text { Cooperation } m \text { ay be useful in the prevention of } \\
\text { competition and conflict between the } \\
\text { participants. }\end{array}$ \\
\hline $\begin{array}{l}\text { Inhabitants should be included by Municipalities in } \\
\text { urban regeneration process with participation } \\
\text { activities. }\end{array}$ & $\begin{array}{l}\text { Applications can be completed sm oothly with } \\
\text { cooperation for local governm ents, NGOs and } \\
\text { inhabitants. }\end{array}$ \\
\hline $\begin{array}{l}\text { Problems about planning can be better ex pressed } \\
\text { with participation activities. }\end{array}$ & $\begin{array}{l}\text { Muricipalities can be played a m editory mission } \\
\text { for providing cooperation between NGOs and } \\
\text { inhabitants. }\end{array}$ \\
\hline $\begin{array}{l}\text { The participation activites are caused lossing of cost } \\
\text { and time. }\end{array}$ & $\begin{array}{l}\text { The process and cost that are created for } \\
\text { cooperation activities (surveys, et) are caused } \\
\text { lossing of effort and time for application }\end{array}$ \\
\hline
\end{tabular}


The participants were consulted on the 'participatory practices' where they would have a better say and 'cooperation' where they would have more responsibility during the transformation process.

NGOs expected the conduct of activities for the creation and sustainability of participatory practices, and also that local administrations allow them to take part in such activities (Figure 9a). A majority of inhabitants, in turn, expected to have training on participatory practices (surveys, consensus, interviews, etc.). Some of the local inhabitants considered that participatory processes would not result in any concrete gain, and that they represent a loss of time and financial resources.

Regarding cooperation, NGOs believed that ideological views will tend to dominate in practice (Figure 9b). Most of the inhabitants believed that cooperation will not be possible due to ideological views, and that transformation efforts would thus not be worth the money or time spent.

\section{Development of Spatial Strategies Based on the Unity of Space, Society, and Politics}

Based on the results of the current situation analysis and field survey, spatial strategies were developed for transformation practices in the Şükran Neighborhood.

- In the implementation area, historical and cultural structures below and above the ground should be identified, preserved and improved.

- In new constructions, inhabitants' expectations for gardens, patios, and number of rooms should be taken into consideration; initiatives should be developed for the preservation of registered buildings; and the potential of historical and cultural assets should be used to enhance the attraction of the space.

- Reconciliation should be preferred to prevent legal problems related to property rights under the urban transformation process. Development (construction) right transfers to proprietors should be considered within the limits of the revised development (construction) plans of the municipality. Since the area is under the risk of disaster; ex-officio solutions should be offered in accordance with the Law No. 6306 on Regeneration of Areas Under the Risk of Disasters in case of any disputes, such that legal problems related to property rights can be resolved. Thus, the cadastral structure should be reorganized at the end of the implementation process.

- Within the context of the planning strategy, standards on the historical characteristics of the area should be developed under the Law No. 6306.

- In order to satisfy the public interest, the implementation should be done within the framework of a certain revised development (construction) plan to reflect the increased land value to the 
public, or increased development (construction) rights should be transferred to satisfy the public interest.

- With respect to urban policy production for the area; the primary expectations from the local administration during the restructuring of problematic areas are increased employment opportunities, production of mass housing, and infrastructure, etc. In this respect, a balanced sectoral development is expected in relation to land use and land functions. This can only be ensured through the development of upper scale policies at city level.

- The results of the field research and surveys are important for determining the suitable method of transformation. In this regard, a transformation method that preserves cultural assets while also ensuring economic dynamism and the restructuring of risky areas and buildings should be preferred.

- A governance approach should be adopted to ensure horizontal and vertical coordination. Thus, planning decisions can be taken based on reconciliation. According to the survey results, both groups believe that due to the ideological views of the local administration, participatory and cooperative practices are a loss of time and financial resources; they also seem to think that their inclusion into the relevant practices is solely an approach for convincing them regarding the relevant practice's utility. Actors should be given more responsibility, and they should be employed and actively involved in the implementation process to encourage them to willingly take part. This requires the development of a comprehensive plan in which the administration should lead the process to build participation and cooperation under the concept of governance.

- With respect to actors and their roles, this study focuses on two groups as representatives of the social structure. Although this framework is not sufficient, the implementation process might become further complicated if the multi-actor structure of urban transformation processes is fully involved in the process. For this reason, those actors who directly or indirectly affect or who are directly or indirectly affected may be assigned as representatives through democratic processes. For example, in the implementation area, those who are influential among the craftsmen may be selected as their representative.

\section{CONCLUSION}

Urban transformation practices in Turkey still have certain issues and shortcomings. To avoid such issues, this study makes recommendations based on the unity of space, society, and politics regarding spatial strategies developed within the framework of a case study.

With the spatial analyses conducted within the scope of the study, it has been revealed that the application area needs to be redeveloped while 
preserving its historical texture. During this process, the invisible and visible cultural and historical assets in the implementation area should be identified, preserved, and improved.

The survey revealed differences in the expectations of different groups from urban transformation. While allocating more resources to mass housing and functions that will increase employment come to the fore among residents' expectations, improving the attraction and design of the space and creating recreational areas are among the leading expectations of NGOs. The results of this survey show that considering the area in terms of housing needs, design attractiveness, employment and economic vitality and recreation according to the expectations of both groups will affect the success of the application. Therefore, within the framework of the analyses on land use and survey, the groups involved in the practice should be consulted, and their experience, knowledge, and requests should be taken into consideration.

NGOs and residents have completely opposite ideas about participation and cooperation in the implementation process. For this point of view not to affect the success of the implementation adversely, it is necessary to focus on creating plans in a cooperative nature. Therefore, the management of participatory and cooperative processes and the concept of governance should be analyzed by local governments to ensure coordination between the actors involved in the implementation. Furthermore, an active role in the awareness and decision-making processes to be created by the actors can play a significant role in the project's ownership.

In conclusion, it can be said that, with the increase in population, cities in Turkey are rapidly developing and undergoing transformation at the same time. To ensure the success and sustainability of this transformation process, issues and deficiencies in practice should be identified, and urban transformation processes should be monitored.

\section{FINANCIAL DISCLOSURE}

The authors declared that this study has received no financial support.

\section{CONFLICT OF INTEREST}

No conflict of interest was declared by the authors.

\section{ETHICS COMMITTEE APPROVAL}

Ethics committee approval was not required for this article.

\section{LEGAL PUBLIC/PRIVATE PERMISSIONS}

In this research, the necessary permissions were obtained from the relevant participants (individuals, institutions and organizations) during the survey, in-depth interview, focus group interview, observation or experiment. 


\section{REFERENCES}

Afacan, Y. (2015). Resident satisfaction for sustainable urban regeneration. Proceedings of the Institution of Civil Engineers - Municipal Engineer, 168(4), 220-234.

Akın, 0. \& Özdemir, D. (2010). A comparative assessment of the European Union and Turkey in the Housing production process and TOKI applications, In Dilek Özdemir, eds. Policy, Legislation and Implementation in Urban Transformation: European Experience, Istanbul Applications, Nobel Broadcast Distribution, pp. 285-316, Ankara, Turkey (in Turkish).

Altunışık, R. Coşku, R. Bayraktaroğlu, S. \& Yıldırım, E. (2010). Research methods in social sciences, SPSS applied, Sakarya Publishing. (in Turkish).

Arnstein, S.R. (1969). A ladder of citizen participation, Journal of the American Institute of Planners, 35, 216-224.

Ay, D. (2019). Diverging community responses to state-led urban renewal in the context of recentralization of planning authority: An analysis of three urban renewal projects in Turkey. Habitat International, 91. https://doi.org/10.1016/j.habitatint.2019.102028

Batuman, B. (2013). City profile: Ankara, Cities, 31, 578-590.

Bektaş, Y. (2014). Bir Kentleşme Stratejisi Olarak Yasanın Kentsel Mekanı Dönüştürmedeki Etkisi : Ankara Örneği. Planning, 24(3), 157-172.

Bostan, M. Erdoğanaras, F. \& Tamer, N.G. (2010). Manufacturing industry replacement process and features in the metropolitan area in Ankara, METU JFA, 27(1), 81-102.

Bozdağ, A. (2015). Analysis of urban regeneration applications in consensus land use planning approach, Thesis (Phd), The Graduate School of Natural and Applied Science S.U. Konya (in Turkish).

Cahantimur, A. I., Öztürk, R. B., \& Öztürk, A. C. (2010). Securing land for urban transformation through sustainable brownfield regeneration - the case of Eskișehir, Turkey. Environment and Urbanization (IIED), 22(2), 241-258. https://doi.org/10.1177/0956247809362641

Dündar, Ö. (2001). Models of Urban Transformation Informal Housing in Ankara, Cities, 18 (6), 391-401.

Edgar, B. \& Taylor, J. (2008). Housing, Urban Regeneration: A Handbook, Chapter 8. Edt. Peter Roberts, Hugh Sykes. British Urban Regeneration Association.

Eğercioğlu, Y., Yakıcl, N., \& Ertan, T. (2016). Urban Decline and Revitalization Project in Izmir-Tire Historical City Center. Procedia Social and Behavioral Sciences, 216, 330-337.

Ercan, M.A. (2011). Challenges and conflicts in achieving sustainable communities in historic neighbourhoods of Istanbul, Habitat International, 35, 295-306.

Eyüboğlu, E., Kubat, A.S. \& Ertekin, Ö. (2007). A New Urban Planning Approach for the Regeneration of an Historical Area within Istanbul's Central Business District, Journal of Urban Design, 12(2), 295-312.

Fabris, L. M. F., Camerin, F., Semprebon, G., \& Balzarotti, R. M. (2020). New 
Healthy Settlements Responding to Pandemic Outbreaks: Approaches from ( and for ) the Global City. The Plan Journal, 5(2), 385-406.

Gainza, X. (2017). Culture-led neighbourhood transformations beyond the revitalisation / gentrification dichotomy. Urban Studies, 54(4), 953970.

Göksu, E. \& Bal, E. (2010). Urban transformation projects in Turkey as a neoliberal spatial development strategy. In Dilek Özdemir, eds. Policy, Legislation and Implementation in Urban Transformation: European Experience, Istanbul Applications, Nobel Broadcast Distribution, pp.256284, Ankara, Turkey (in Turkish).

Günay, Z, \& Dökmeci, V. (2012). Culture-led regeneration of Istanbul waterfront: Golden Horn Cultural Valley Project, Cities, 29, 213-222.

Güzey, Ö. (2009). Urban regeneration and increased competitive power : Ankara in an era of globalization. Cities, 26(1), 27-37.

Güzey, Ö. (2016). The last round in restructuring the city: Urban regeneration becomes a state policy of disaster prevention in Turkey. Cities, 50, 40-53.

Hart, T. \& Johnston, I. (2006). Employment, Education and Training, Urban Regeneration: A Handbook, Chapter 7. Edt. Peter Roberts, Hugh Sykes. British Urban Regeneration Association.

Iban, M. C. (2020). Lessons from approaches to informal housing and noncompliant development in Turkey: An in-depth policy analysis with a historical framework. Land Use Policy, 99.

Işık, O. (1995). The unwritten history of constructivism: Observations on the condition of presence and development in small-scale production in the housing sector in Turkey, Architecture Journal, 261, 43-45. (in Turkish).

Jacobs, B. \& Dutton, C. (2004). Social and Commuity Issues, Urban Regeneration: A Handbook, Chapter 6. Edt. Peter Roberts, Hugh Sykes. British Urban Regeneration Association.

Jeffrey, P. \& Pounder, J. (2002). Physical and Environmental Aspects, Urban Regeneration: A Handbook, Chapter 5. Edt. Peter Roberts, Hugh Sykes. British Urban Regeneration Association.

Kayasü, S., \& Yetişkul, E. (2014). Evolving legal and institutional frameworks of neoliberal urban policies in Turkey, METUJFA, 31 (2), 209222.

Kreukels, A. M. \& Spit, T. J. M. (1990). Public-private partnership in the Netherlands, Journal of Economic and Social Geography, 81 (5), 388-392.

Kocabaş, A. (2006). Urban conservation in Istanbul: evaluation and reconceptualisation, Habitat International, 30, 107-126.

Lees, L. (2018). Handbook of Gentrification Studies. Edt. Loretta Lees, Martin Phillips. Edward Elgar Publishing, Cheltenham and Northampton.

Levy, D. K., Comey, J., \& Padilla, S. (2006). In the face of Gentrification Case Studies of local efforts to mitigate displacement. J. Affordable Hous. \& Cmty. Dev. L., 238.

Li, J. (2020). Culture and tourism-led peri-urban transformation in China 
- The case of Shanghai. Cities, 99.

Linchfield, D. (1992). Urban Regeneration for the 1990s, London Planning Advisory Committee, London

Muñoz-gielen, D. (2012). Urban governance, property rights, land readjustment and public value capturing. European Urban and Regional Studies, 21(1), 1-19.

Noon, D. Smith-Canham, J. \& Eagland, M. (2000). Economic Regeneration and Funding. Urban Regeneration: A Handbook, Chapter 4. Edt. Peter Roberts, Hugh Sykes. British Urban Regeneration Association.

Oakley, S. (2011). Re-imagining City Waterfronts: A Comparative Analysis of Governing Renewal in Adelaide, Darwin and Melbourne Reimagining City Waterfronts: A Comparative Analysis of Governing Renewal in Adelaide, Darwin and Melbourne. Urban Policy and Research, 29(3), 221-238.

Oatley, N. (2000). New Labour' s Approach to Age-old Problems Renewing and revitalising poor neighbourhoods \pm the national strategy for neighbourhood renewal. Local Economy, 15(2), 86-97.

Öngel, F. S. (2013). Marketed cities and labor. In: A. Koca, C. O. Calıskan, E. Kaya and G. Akgun, eds. Defending Cities, Space, Society and Politics. Nota Bene Publishing, pp:17-20, Ankara, Turkey, (in Turkish).

Özdemir, D. (2010). The changing meanings of urban transformation in Western Europe Turkey reflections. In Dilek Özdemir, eds. Policy, Legislation and Implementation in Urban Transformation: European Experience, Istanbul Applications, Nobel Broadcast Distribution, pp.1-34, Ankara, Turkey, (in Turkish).

Özden, P. (2010). A critical look at the policies and practices of urban transformation in Turkey. In Dilek Özdemir, eds. Policy, Legislation and Implementation in Urban Transformation: European Experience, Istanbul Applications, Nobel Broadcast Distribution, pp. 194-225, Ankara, Turkey, (in Turkish).

Özgür, E. F. (2013). Urban design projects and the planning process : The Kadıköy Old Market Area Revitalization Project and the Kartal Industrial Area Regeneration Project. Cities, 31, 208-219.

Öztürk, P.K. (2006). Urban Transformation of Ottoman Port Cities In The Nineteenth Century: Change From Ottoman Beirut To French Mandatory Beirut. The Graduate School of Social Sciences, METU, 164.

Palancioğlu, H. M., \& Cete, M. (2014). Land Use Policy The Turkish way of housing supply and finance for low- and middle-income people. Land Use Policy, 39, 127-134.

Roberts, P. (2004). The evaluation, definition and purpose of urban regeneration. Urban Regeneration: A Handbook, Editorial Arrangement, Chapters 1 and 14. Edt. Peter Roberts, Hugh Sykes. British Urban Regeneration Association.

Roberts, P. \& Skyes H. (2000). Urban Regeneration: A Handbook. Editorial Arrangement, Chapters 1 and 14. Edt. Peter Roberts, Hugh Sykes. British Urban Regeneration Association. 
Roman'czyk, K. M. (2015). Towards urban governance : Twenty years of neighbourhood contracts in the Brussels-Capital Region. Cities, 44, 1-8.

Rosa, D. La, Privitera, R., Barbarossa, L., \& Greca, P. La. (2017). Landscape and Urban Planning Assessing spatial benefits of urban regeneration programs in a highly vulnerable urban context : A case study in Catania, Italy. Landscape and Urban Planning, 157, 180-192.

Sklair, L. (2017). The icon project: architecture, cities and capitalist globalization. New York: Oxford University Press.

Stöhr, W. (1989). Regional policy at the crossroads: an overview, in L. Albrechts, F. Moulaert, P. Roberts and E. Swyngedlouw (eds.) Regional Policy at the Crossroads: European Perspectives, Jessica Kingsley, London.

Stein, S. (2019). Capital City. Gentrification and the real estate state. London-New York: Verso.

Swyngedouw, E. (2005). Governance Innovation and the Citizen: The Janus Face of Governance-beyond-the-State. Urban Studies, 42(11), 1991-2006.

Tallon, A., (2010). Urban renaissance in England: urban reflections and critical evaluations. In Dilek Özdemir, eds. Policy, Legislation and Implementation in Urban Transformation: European Experience, Istanbul Applications, Nobel Broadcast Distribution, pp.79-98, Ankara, Turkey, (in Turkish).

Tekeli, İ. (2009). It is quoted from the speech made at the Symposium on the Last Ten Years of Planning and Architecture. Ylldız Technical University, Architecture Faculty. (in Turkish).

Topçu, H. (2017). Waterfronts Revisited, European ports in a historic and global perspective. Edt. Heleni Porfyriou, Marichela Sepe. London-New York: Routledge.

Turk, S. S., Tarakci, S., \& Gürsoy, N. (2020). A large-scale urban renewal project in a vicious cycle of commons and anticommons : The Fikirtepe case (Istanbul , Turkey). Habitat International, 102.

Uysal, Ü. E. (2012). An urban social movement challenging urban regeneration : The case of Sulukule , Istanbul. Cities, 29, 12-22.

Uzun, B. \& Şimşek, N. Ç. (2015). Upgrading of illegal settlements in Turkey; the case of North Ankara Entrance Urban Regeneration Project, Habitat International, 49, 157-164.

Üstün, G. (2009). Legal Aspects of Urban Transformation. XII Publishing. ISBN 978-605-5865-37-5. (in Turkish).

Yllmaz, A. (2007). Notes on the Transformation of Turkish Public Administration in the EU Harmonization Process. University of Dumlupınar, The Journal Social Sciences, 17, 215-214. (in Turkish).

Williamson, W., \& Ruming, K. (2019). Urban Renewal and Public Participation in Sydney: Unpacking Social Media Strategies and Use for Contesting Consensus Urban Renewal and Public Participation in Sydney: Unpacking Social Media Strategies and Use for Contesting Consensus. Urban Policy and Research, 1-17.

Zhang, S. (2014). Land-centered urban politics in transitional China - Can they be explained by Growth Machine Theory? Cities, 41, 179-186. 
https://doi.org/10.1016/j.cities.2014.02.010

Zhu, L. \& Huang, Y. (2015). Planning for sustainable inner city regeneration in China. Proceedings of the Institution of Civil Engineers Municipal Engineer, 168(4), 244-252.

Visuals' sources based of internet

Konya general overwiev (2016). Figure was created by combining the specified resources by the author.

https://www.tursab.org.tr/pic_lib/bigSize/resimgalerisi/113/konya_11 3_1244153.jpg [09.02.2016]

http://ruzgarorganizasyon.com/semazen-gosterisi/ [09.02.2016]

https://tr.wikipedia.org/wiki/Konya\#/media/File:Latrans-

Turkey_location_Konya.svg 15946885 [02.05.2016]

http://www.skylife.com/tr/2013-02/herkesin-ait-oldugu-yer-

catalhoyuk (29.04.2016)

https://artasmedia.files.wordpress.com/2015/03/north-west-bullpainting.jpg [29.09.2016]

https://www.tursab.org.tr/pic_lib/bigSize/resimgalerisi/113/konya_m eke_golu-1_113_1243151.jpg [09.02.2016]

\section{Resume}

Aslı Bozdă̆, is an assistant professor in Geomatics Engineer at the Niğde Ömer Halisdemir University in Niğde, Turkey. Her research focuses on urban and regional planning, environmental planning, urban renewal, GIS, collaborative land use policy, land consolidation, cadastre and real estate valuation. Her recent studies integrate urban and environmental planning and spatial prediction (air pollution pm10 and Carbon footprint) with GIS and machine learning.

Saban Inam, is an assistant professor in Geomatics Engineer at the Konya Technical University in Konya, Turkey. His research focuses on urban redevelopment, arrangement-based zoning application, urban renewal, collaborative land use policy, land consolidation and cadastre. His recent studies integrate value-based application in urban area design studies. 